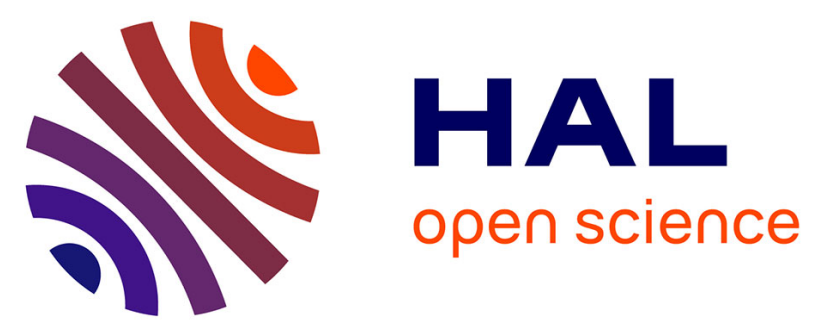

\title{
Retrogressive thaw slumps on ice-rich permafrost under degradation: Results from a large-scale laboratory simulation
}

François Costard, L. Dupeyrat, A. Séjourné, F. Bouchard, A. Fedorov, B. Saint-Bézar

\section{To cite this version:}

François Costard, L. Dupeyrat, A. Séjourné, F. Bouchard, A. Fedorov, et al.. Retrogressive thaw slumps on ice-rich permafrost under degradation: Results from a large-scale laboratory simulation. Geophysical Research Letters, 2021, 48 (1), 10.1029/2020GL091070 . hal-03065348v2

\section{HAL Id: hal-03065348 \\ https://hal.science/hal-03065348v2}

Submitted on 14 Oct 2021

HAL is a multi-disciplinary open access archive for the deposit and dissemination of scientific research documents, whether they are published or not. The documents may come from teaching and research institutions in France or abroad, or from public or private research centers.
L'archive ouverte pluridisciplinaire HAL, est destinée au dépôt et à la diffusion de documents scientifiques de niveau recherche, publiés ou non, émanant des établissements d'enseignement et de recherche français ou étrangers, des laboratoires publics ou privés. 


\section{Geophysical Research Letters}

\author{
RESEARCH LETTER \\ 10.1029/2020GL091070 \\ Key Points: \\ - Retrogressive thaw slumps \\ (RTS) result from the thermal \\ destabilization of ice-rich permafrost \\ as a consequence of increasing \\ subsurface temperature \\ - Experimental RTS were designed \\ to simulate the thawing of ice- \\ rich permafrost with vertical and \\ horizontal ice layers \\ - Our laboratory simulations show \\ how ground-ice heterogeneities \\ influence RTS development
}

Supporting Information:

- Text S1

- Figure S1

- Figure S2

- Data Set S1

- Data Set S2

- Movie S1

- Movie S2

Correspondence to:

F. Costard,

francois.costard@universite-parissaclay.fr

Citation:

Costard, F., Dupeyrat, L., Séjourné A., Bouchard, F., Fedorov, A., \& SaintBézar, B. (2020). Retrogressive thaw slumps on ice-rich permafrost under degradation: Results from a large-scale laboratory simulation. Geophysical Research Letters, 47, e2020GL091070. https://doi.org/10.1029/2020GL091070

Received 30 SEP 2020

Accepted 19 NOV 2020

(c) 2020. American Geophysical Union. All Rights Reserved.

\section{Retrogressive Thaw Slumps on Ice-Rich Permafrost Under Degradation: Results From a Large-Scale Laboratory Simulation}

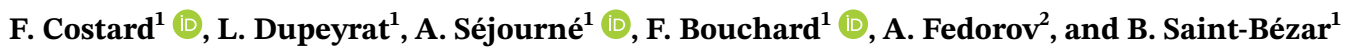 \\ ${ }^{1}$ Géoscience Paris Sud (GEOPS), CNRS/Université Paris-Saclay, Orsay, France, ${ }^{2}$ Melnikov Permafrost Institute, Russian \\ Academy of Sciences, Yakutsk, Russia
}

\begin{abstract}
In the ice-rich permafrost of the Arctic regions, thermokarst erosion on slopes induces the formation of large-scale retrogressive thaw slumps (RTS). They have significant geomorphological, hydrological, and biogeochemical impacts on the landscape. Further research is thus needed to better understand the respective effect of ice content and permafrost heterogeneities on the dynamics of these erosional features. Here, we present results of a full-scale physical modeling of RTS development in a cold room. The experimental setup was designed to simulate and compare two ground-ice settings (ice wedges, icy layers) with the thawing of ice-poor permafrost (i.e., reference model). Our results show that the melting of the icy layers induces a loss of decohesion of the overlapping frozen soil. The heterogeneous frozen soil with ice wedges needs a longer time until degradation, but undergoes a stronger and faster decohesion of its structure during the thawing phase.
\end{abstract}

\section{Introduction}

Over the last few years, various studies have documented significant impacts of recent global warming across the Arctic since the mid-twentieth century, with a preferential thermal degradation of ice-rich permafrost and the related release of previously sequestered carbon (e.g., Grosse et al., 2011; Romanovsky et al., 2010). These studies indicate a sensitivity of cold Arctic permafrost to climate-driven thermokarst (thaw) initiation (Olefeldt et al., 2016). The development of thermokarst results from the thermal destabilization of ice-rich permafrost as a consequence of the increase in subsurface temperature (French, 2017; Soloviev, 1973). Over the last decades, this ice-rich permafrost has been highly vulnerable and prone to extensive degradation within the continuous permafrost zone of Eurasia and North America (Lewkowicz \& Way, 2019; Olefeldt et al., 2016).

Retrogressive thaw slumps (RTS) represent a dynamic form of thermokarst. They expand inland by melting of exposed ground ice in the headwall to form landslide-like U-shaped scars (Lantuit \& Pollard, 2008). In the western Canadian Arctic, widespread permafrost degradation accompanied by active RTS development is mostly observed in ice-rich formerly glaciated landscapes (Kokelj et al., 2017; Murton et al., 2017; Nitze et al., 2018; Olefeldt et al., 2016; Rudy et al., 2017). These ice-rich areas contain buried glacier ice that has been preserved under permafrost conditions (Rudy et al., 2017). They are present in the form of horizontal massive ice layers. In eastern Siberia, RTS are mostly developed in the Yedoma (Pleistocene-aged) ice complex area (Opel et al., 2019). In central Yakutia (CY), the upper section of permafrost contains Pleistocene ice-rich sediments, up to $20-50 \mathrm{~m}$ in thickness, containing $~ 70 \%-80 \%$ of ice by volume (Schirrmeister et al., 2020; Soloviev, 1973). The Yedoma ice complex is dominated by huge ice wedges up to a few meters wide and 15-25 m high within sandy deposits (Opel et al., 2019; Shepelev et al., 2020). In some places, these large-scale ice wedges can be continuous and form a massive horizontal ice layer at the base (Opel et al., 2019). In CY, RTS are smaller than in the High Arctic. Amphitheater-shaped slump hollows are 30-50 m wide and are characterized by (1) their concave profile of collapsed banks and (2) highly degraded conical polygons (Figure 1) with wide troughs referred to as "baydjarakhs" (Soloviev, 1979). This icerich permafrost is characterized by its medium and/or fine sand $\left(D_{50} 200-300 \mu \mathrm{m}\right)$ and silty material $\left(D_{50}\right.$ 18-30 $\mu \mathrm{m}$ ) of Quaternary lacustrine or aeolian (loessic) origin (Schirrmeister et al., 2020; Soloviev, 1973). These sediments contain $\sim 30 \%-40 \%$ of ice by volume, in addition to large syngenetic ice wedges (Strauss et al., 2017; Ulrich et al., 2014). 


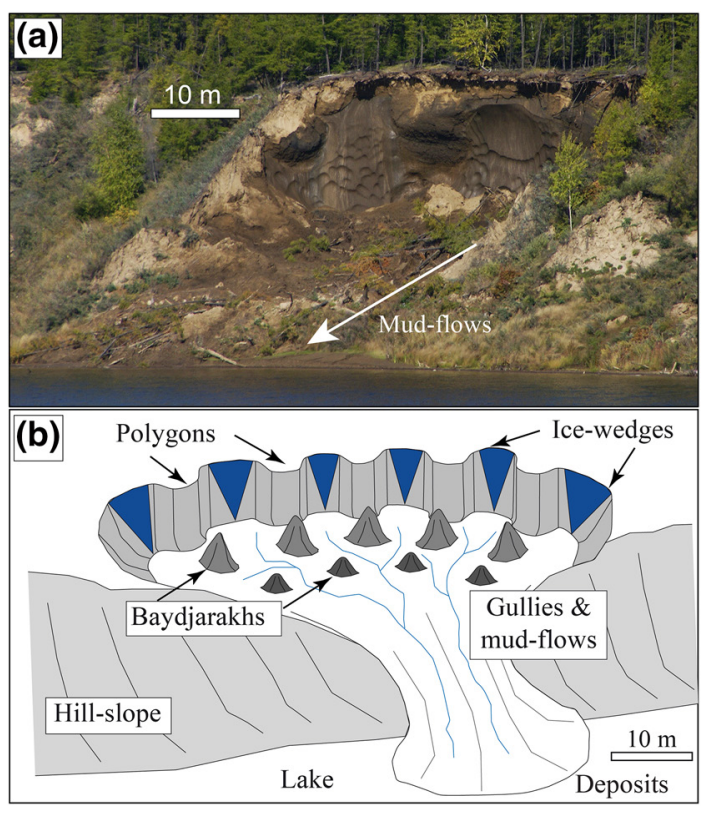

Figure 1. (a) Headwall of RTS along a thermokarst lake in CY (eastern Siberia). Permafrost with alluvial sandy loam containing up to $40 \%-50 \%$ of ice by volume and syngenetic ice wedges of $\sim 7 \mathrm{~m}$ in thickness. (b) The localized melting of ice wedges along the banks of thermokarst lakes forms highly degraded conical polygons with wide troughs (baydjarakhs). These typical structures are indicative of heterogeneous ice-rich permafrost with a preferential erosion along ice wedges.
Several studies estimated the development of RTS in the High Arctic with extended photo time series (30 years). Headwall retreat rates range from 0.5 to $1 \mathrm{~m}$ year ${ }^{-1}$ along thermokarst lakes in the tundra uplands of the Mackenzie Delta, Canada (Lantz \& Kokelj, 2008) to an average up to $0.68 \mathrm{~m}_{\text {year }}^{-1}$ and $29.0 \mathrm{~m}^{3} \mathrm{~m}^{-1}$ year $^{-1}$ on the coast of Herschel Island, Canada, next to the Beaufort Sea (Lantuit \& Pollard, 2008; Obu et al., 2016). Headwall retreat rates of up to $13 \mathrm{~m} \mathrm{year}^{-1}$ were recently observed in the western coast of Kolguev Island, Russia (Kizyakov et al., 2013). In CY, the maximal average headwall retreat of these RTS can reach $3.16 \mathrm{~m} \mathrm{year}^{-1}$ for the 2012-2013 period (Séjourné et al., 2015), although maximal values of $30 \mathrm{~m}$ year $^{-1}$ were recorded at the Batagay megaslump in Yakutia (Opel et al., 2019). With a length of more than $1,000 \mathrm{~m}$, a width of 800 and $60 \mathrm{~m}$ high headwalls in 2019, this mega-RTS is representative of three typical cryolithological types of permafrost at a single site. It is characterized by its ice-rich Yedoma permafrost close to the surface, underlain by ice-poor sands, while at its base a pure groundice layer is present (Shepelev et al., 2020). In close association with the erosion of RTS, small mud flows settling on gentle slopes are observed from melted ice-wedge network and contribute to the transport of sediments, dissolved elements, and meltwater from the melting of ice wedges (Figure 1a). These RTS liberate both soluble materials and organic carbon accumulated in the sedimentary deposits that are transported by runoff (Shakil et al., 2020; Vonk et al., 2015). The abrupt thawing of ice-rich permafrost is thus a major issue because of the positive feedback on global climate (Schuur et al., 2008; Turestsky et al, 2020).

The possible causes of present-day initiation of thermokarst are numerous but their interrelations are not well understood. According to Ward Jones et al. (2019), record summer warmth in 2011 and 2012 in the Canadian Arctic promoted thermokarst initialization in previously unaffected terrain. Permafrost degradation is always initiated by deepening of the active-layer as a consequence of an increase in subsurface temperature (Fedorov \& Konstantinov, 2009; Fedorov et al., 2014). RTS are initiated by a variety of mechanisms that expose ice-rich sediments, including mechanical erosion by fluvial processes, wave action, thermally driven subsidence along the banks, and mass-wasting (Burn \& Lewkowicz, 1990; Kokelj et al., 2017; Lacelle et al., 2010; Lantuit \& Pollard, 2008; Wolfe et al., 2001). According to Segal et al. (2016), climate change, in conjunction with increases in air temperature and precipitation, induces an acceleration of RTS activity. According to Séjourné et al. (2015), RTS in CY mainly occur along the south-to southwest-facing banks of thermokarst lakes due to solar insolation and increased air temperature. However, the timings of this recent increase over the last few decades and its links to climate have not been fully established (Lantuit \& Pollard, 2005; Lantz \& Kokelj, 2008; Wolfe et al., 2001). Local differences in recent erosion rates across the circumpolar Arctic may be due to a difference in local climate, headwall height, and ice content (Kokelj \& Jorgenson, 2013). Other authors suggest that the presence of massive ground ice (ice wedges, massive segregated ice, and buried glacier ice) is a precondition for RTS development (Lantuit et al., 2012; Leibman et al., 2008). While it was observed that RTS in CY develop in Yedoma ice complex terrain with huge syngenetic ice wedges (Figure 1b), the heterogeneous structure of ice-rich permafrost and its subsequent influence on thermokarst degradation has not been analyzed. The relative importance of the main parameters affecting RTS is, however, difficult to assess in the field. Numerous factors work simultaneously, and their interdependence makes their separate analysis difficult. Physical modeling provides a unique tool for a more detailed monitoring compared to field observations.

Here, we present results of a full-scale physical modeling of RTS development in a cold room. For this purpose, the experimental RTS were designed to simulate the thawing of ice-rich permafrost with various heterogeneities (ice wedges, icy layers) that were supposed to be representative of RTS development in CY. In a first experimental setup, we simulated artificial ice wedges (vertical ice layers), which are common in large parts of continuous permafrost across the Northern Hemisphere (i.e., polygonal landscapes and Yedoma 

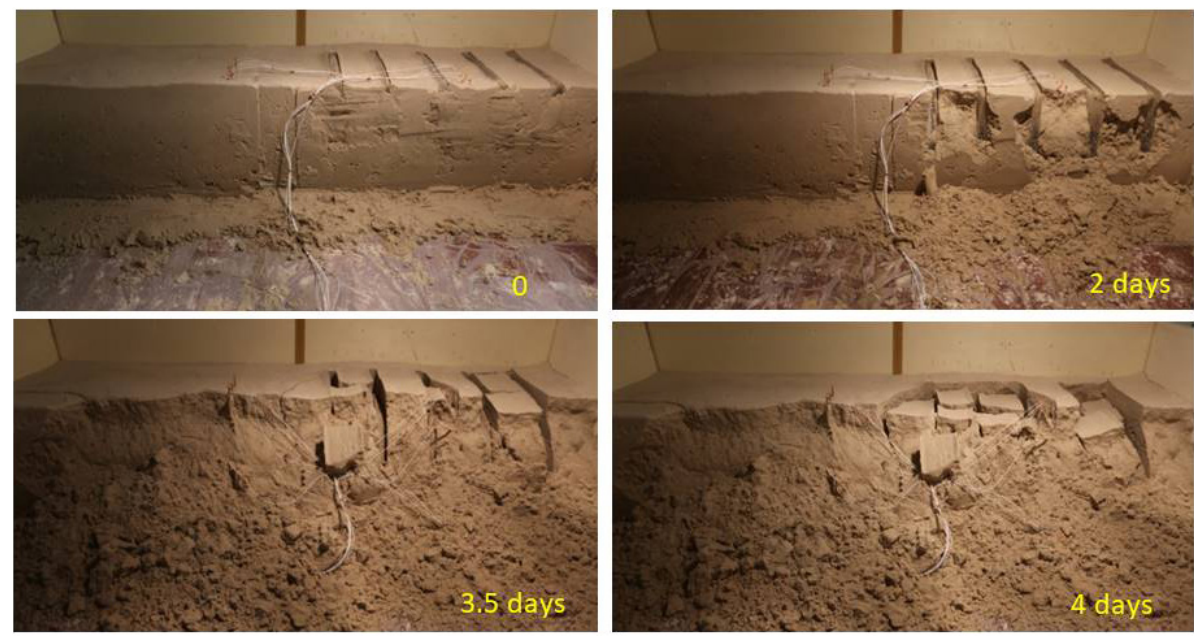

Figure 2. RTS experiment no. 1 (with ice wedges) of $2.5 \mathrm{~m} \times 2.5$ wide and $0.5 \mathrm{~m}$ height showing on the left side a homogeneous frozen soil and on the right side the same frozen soil (saturated fine sand) with additional artificial ice wedges. The thick vertical brown line on the top of each photo separates left from right part. Active erosion due to the presence of ice wedges is observed on the right side of the experiment. White cables correspond to temperature sensors.

ice complex). In a second setup, horizontal ice layers mimic a second type of ice-rich permafrost that might find its natural expression in formerly glaciated Arctic landscapes with soft sediments and large masses of segregated ice or buried glacier ice. Each experimental setup was compared to reference frozen ground with no excess ice. Therefore, this study is representative of three typical cryolithological types of permafrost in unconsolidated material, which cover several hundreds of thousands of $\mathrm{km}^{2}$ in the Arctic.

\section{Experimental Setup}

Physical modeling of RTS was undertaken using large-scale frozen soils in a temperature-controlled chamber. The major purpose of the experiment was to examine the respective effects of different ground-ice content and type affecting the ground thermal regime and vulnerability to subsidence. We used the cold room at the GEOPS laboratory (University Paris Saclay, France) dedicated to the physical modeling in periglacial geomorphology. The specificity of our experiments was to simulate the thawing of ice-rich permafrost, compared to the thawing of ice-poor permafrost (i.e., reference conditions). In a first experimental setup (experiment no. 1), we worked with artificial ice wedges (vertical ice layers, see S1), which are common in large parts of continuous permafrost across the Northern Hemisphere (i.e., polygonal landscapes). In a second setup (experiment no. 2), we worked with horizontal ice layers mostly typical of formerly glaciated Arctic landscapes with soft sediments and large masses of segregated ice or buried glacier ice (see S2). Our experiment is composed of a rectangular box of $2.5 \mathrm{~m} \times 2.5 \mathrm{~m}$ wide and $0.5 \mathrm{~m}$ deep in which fine sand $\left(D_{50}=200 \mu \mathrm{m}\right)$ was saturated with water (Figure 2). Here, we used the grain size distribution of Bayeux sand as an analog to sands from the banks of most RTS in CY. The basal slope was $5^{\circ}$ for the release of meltwater overflow during the thawing phase. A foam rubber was placed all around the experiment to ensure thermal insulation. For each experiment, the sediment structure was homogeneous and had a water content of $20 \%$ by volume. A well-proven technique was used to create a homogeneous porous medium of more than 1 ton of saturated soil (Costard et al., 2003). To obtain the optimal porosity at water saturation, we first mixed the sand with water to a wet density of $1.81 \mathrm{~g} \mathrm{~cm}^{-3}$ corresponding to the "Proctor compaction" technique (Costard et al., 2003). We manually compacted layers of $10 \mathrm{~cm}$ each and then put them on top of each other until $0.5 \mathrm{~m}$ thickness was reached. Such technique allows a parametric control on a homogeneous block of about 1 ton of already saturated material with a volumetric water content of $20 \%$. There might be some small interfaces (thin unconformities), but they remain insignificant.

In order to evaluate the effect of permafrost heterogeneities on the development of RTS, we artificially built vertical and horizontal ice layers to respectively mimic ice wedges and icy beds (volumetric ice content of $100 \%$ ). Before the freezing phase, each icy block was installed within the right side of the experiment (see 


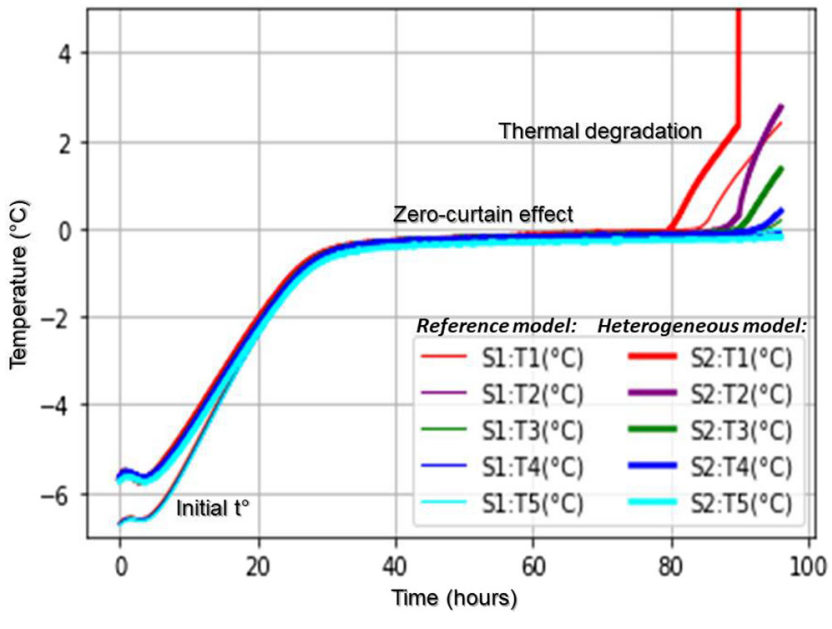

Figure 3. Experimental setup no. 1: evolution of temperature in homogeneous frozen soil (thin lines: S1) and heterogeneous frozen soil with artificial ice wedges (bold lines: S2). A first series of five sensors (S1:T1 to S1:T5), spaced every $5 \mathrm{~cm}$, was placed in the homogeneous frozen soil at a depth of $20 \mathrm{~cm}$. A similar series of sensors was placed in permafrost with ice heterogeneities (S2:T1 to S2:T5). In both blocks, the temperature is similar in the first heating stage and in the following zerocurtain effect stage. After melting, greater temperatures are observed in the heterogeneous permafrost compared to the homogeneous one.
Figures S1 and S2). Finally, all the material was frozen in the cold room at $-25^{\circ} \mathrm{C}$ and then progressively reheated at $-10^{\circ} \mathrm{C}$ (Figures $\mathrm{S} 3$ and S4). This technique allowed us to prepare homogeneous samples with reproducible densities and without ice segregation (Costard et al., 2003). Figures 2, S1, and S2 show the homogeneous model S1 (or reference model) on the left and the heterogeneous model S2, which corresponds to an icerich permafrost with a total of $30 \%$ ice by volume, on the right. The size, geometry, and spacing of these icy blocks within the frozen soil represent a simplification of the natural setting, but the main objective here was to understand the influence of heterogeneities on permafrost degradation from a strictly thermal point of view.

Figure 2 presents the case of RTS development in an ice-wedge setting with pure ice blocks of $5 \mathrm{~cm}$ thick. In experiment no. 2, we added horizontal heterogeneities (pure icy layers) instead of ice wedges (Figure S2). In that experiment, we artificially built icy layers of $10 \mathrm{~cm}$ in thickness and set them up in the right part of the experiment in the cold room (Figure S2). We used the same protocol as for the experiment no. 1 for preparing the frozen soil. The left side of the experiment corresponds to the reference model with saturated and homogeneous frozen ground. All the models were instrumented using 10 temperature sensors (platinum resistance thermometers Pt100 with $\pm 0.1^{\circ} \mathrm{C}$ accuracy) to survey the freezing and thawing front versus time. A first series of five sensors, spaced every $5 \mathrm{~cm}$, was placed in the homogeneous frozen soil at a depth of $20 \mathrm{~cm}$. A similar series of sensors was placed in the frozen soil with ice heterogeneities (Figures S1 and S2). During each simulation, we also analyzed the development of associated degradation landforms using time-lapse photography with a video camera (Figures S5 and S6). This allows later analysis of the repeated observation of permafrost degradation. For each experiment, we compared ice-rich permafrost degradation (with a total of $30 \%$ ice by volume) with a reference model (homogeneous permafrost with $20 \%$ ice by volume). In these experiments, we assumed that the scale effect was not a limiting factor. Here, we restricted our approach to the relative importance of the heterogeneities (ice wedges, icy layers) and their thermal influence on permafrost degradation.

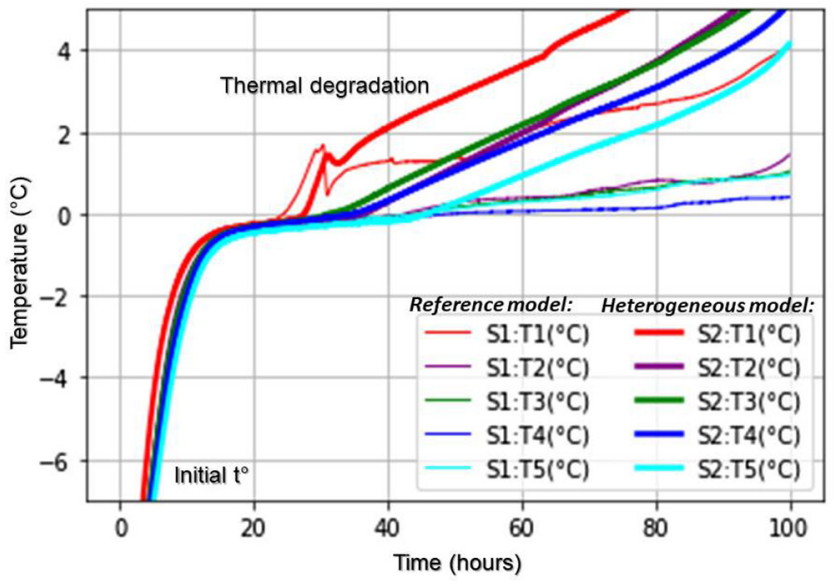

Figure 4. Experimental setup no. 2: evolution of temperatures of modeled heterogeneous permafrost (bold lines: S2) with horizontal heterogeneities (icy layers). Thin lines (S1) correspond to the homogeneous frozen soil (reference model).

\section{Results and Discussion}

Our objective was to test not only different scenarios (different types of heterogeneities) but also different environments. Therefore, we tested permafrost thawing with different initial temperatures $\left(-6^{\circ} \mathrm{C}\right.$ and $\left.-10^{\circ} \mathrm{C}\right)$ and different warming conditions (slight and severe). Figure 3 shows the typical case of a slight warming, whereas Figure 4 presents a more severe scenario (i.e., with a steeper warming phase).

For experiments no. 1 and no. 2, we started to analyze the data recording when all temperatures in the frozen ground were stabilized at around $-6^{\circ} \mathrm{C}$ and $-10^{\circ} \mathrm{C}$, respectively. We performed a systematic measurement of the thermal wave propagation from the 10 Pt100 sensors during the warming phase (Data sets S3 and S4). Three main stages within that warming phase were recorded (Figures 3 and 4): (i) The first stage corresponds to a rapid increase in the temperature monitored for all sensors, within approximately $24 \mathrm{~h}$, with all sensors reaching $0^{\circ} \mathrm{C}$. (ii) The second stage corresponds to a period of relatively stable temperatures around $0^{\circ} \mathrm{C}$ due to the zero-curtain effect (latent heat release). A considerable amount of heat has to warm the ground up to the melting point before ablation can proceed, in agreement with recent investigations on 
temperature-dependent RTS development (Zwieback et al., 2018). (iii) The third stage starts when sensors record positive temperatures.

In experiment no. 1, the reference model (left side of the experiment in Figure 2) showed a relatively slow rise of temperatures (Figure 3). On the contrary, the heterogeneous frozen soil (right side of the experiment in Figure 2) showed a rapid increase of soil temperature, notably faster than the reference model (Figure 3). From a morphological point of view (Figures 2 and S5), the homogeneous block (reference model) remains stable (without any deformation, even after thawing during the warming phase), while the heterogeneous one shows dramatic evolutions (slumping, subsidence). In experiment no. 2 with horizontal heterogeneities (icy layers), again the reference model (homogeneous frozen soil) remained mechanically stable without subsidence, even after complete thawing (Figure S6). On the contrary, the heterogeneous frozen soil with icy layers showed a clear subsidence due to the melting of the excess ice. From a thermal point of view, we can observe a relatively faster warming of the heterogeneous frozen soil and a relatively colder temperature for the reference model (Figure 4). The analysis of the time-lapse photography (Figure S5) clearly shows the evolution of the individual blocks of permafrost in between ice wedges (i.e., modeled polygon centers) toward a hummocky morphology similar to the development of high-centered polygons (i.e., baydjarakhs). Our experiments clearly show the detachment and vertical subsidence of individual blocks along ice wedges and the subsequent formation of "mud" flow at the basal slope due to the basal concentration of oversaturated sediments (Figure S5), in agreement with previous laboratory work focused on rainfall-induced slope failures (Tohari et al., 2007).

In experiment no. 1, the efficient warming in heterogeneous soil can be related to the melting of ice wedges (Figure 2) and the formation of associated voids along the ice wedges that allow for a better heat diffusion within the thawing soil. In fact, during the thawing phase, the progressive melting of ice wedges (excess ice) induces a larger heat capacity of liquid water that enhances temperature increase of the soil. All the experiments showed that ice wedges increase the preferential erosion during the warming phase and supply meltwater to the thawing frozen interface, which accelerates basal slumping. These observations are in agreement with field observations of RTS from Lantuit et al. (2012) and Séjourné et al. (2015). For experiment no. 2, the melting of the icy layers induces a loss of cohesion of the overlapping frozen soil (Figure S6: video material) and a better warm air circulation within the soil. These results indicate that discontinuities (ice wedges, icy layers) in frozen soils are much more prone to intense thermal degradation (warming and thermokarst development) compared to homogeneous and ice-poor permafrost. Our laboratory results are in agreement with recent investigations along the Batagay thaw slump in Yakutia, where the presence of a basal horizontal ice layer of merged ice wedges is the precondition for its deep incision, while the continuous presence of large ice wedges close to the surface seems to be decisive for its large areal extend and exponential growth (Opel et al., 2019).

\section{Conclusions}

The underpinning question of our study was to evaluate the main controlling factors of the formation of RTS. Cryogeological (granulometry, ice content, and type) and climatological conditions differ greatly across regions where RTS can be observed. We simulated two major ground-ice settings (ice wedges and buried massive ice) compared to a reference model (low ice content). Therefore, this study is representative of three typical cryolithological types of permafrost, which can be found at one site together (Batagay megaslump in CY). Our study allows a normalized view on RTS development assuming equal thermal, volumetric ground-ice and grain size conditions and contributes to a better understanding of the relative contribution of heterogeneities, during permafrost degradation processes. Our laboratory simulations attest the efficiency of heterogeneities that control thermokarst and RTS development by two main mechanisms: (i) the strong decohesion of its structure during the thawing phase and an easier circulation of warm air (Figures 3 and 4) and (ii) the excess of water from the preferential melting in ice-rich permafrost, which increases the slumping effect (Figures S5 and S6).

We calculated the onset of degradation for each experimental setup using the duration of the zero-curtain effect. The moderate initial temperature and the slight warming phase of model 1 (ice wedges, Figure 3) induce a longer onset of degradation than the one for model 2 (icy layers under a severe warming condition, 
Figure 4). The ice-wedge type needs more time before degradation, but then this degradation occurs more rapidly compared to model 2 (icy layers). Our experimental approach suggests that the ice-wedge setting strongly increases the efficiency of RTS development.

This study provides a better understanding of how ground-ice heterogeneities influence RTS development, hence serving as a point of reference for future in situ studies of periglacial geomorphic processes and their impacts on the carbon cycle in the Arctic.

\section{Authors Contributions}

F.C. conceived, designed, and carried out the cold-room experiment. A.S. and F.B. developed the hypothesis and its implications. L.D. created and performed calculations of the thermal database, and B.S.-B. and A.F. guided the research effort and discussions. The manuscript was collectively written by F.C., A.S., and F.B. All authors provided input on the manuscript and the broader implications of this work.

\section{Data Availability Statement}

All data from our cold chamber at Orsay (Université Paris-Saclay) are presented in the supporting information S1-S5. These data are also available on the repository PANGAEA Data Archiving \& Publication: https:// doi.pangaea.de/10.1594/PANGAEA.921498. We thank the Editor, M. Fritz, and an anonymous reviewer for their constructive comments and questions, which substantially improved the quality of our manuscript.

\section{References}

Acknowledgments
Authors are funded by the Labex IPSL, the GDR2012 Arctique: Enjeux pour l'Environnement et les Sociétés, and the Agence Nationale de la Recherche (ANR) through the Make Our Planet Great Again (MOPGA) initiative (Program d'investissements d'avenir - project no. ANR-17-MPGA-0014). Assistance of the Melnikov Permafrost Institute of Yakutsk for field studies is gratefully acknowledged.
Burn, C. R., \& Lewkowicz, A. G. (1990). Retrogressive thaw slumps. Canadian Geographer, 34, 273-276. https://doi. org/10.1111/j.1541-0064.1990.tb01092.x

Costard, F., Dupeyrat, L., Gautier, E., \& Carey-Gailhardis, E. (2003). Fluvial thermal erosion investigations along a rapidly eroding river bank: Application to the Lena river (central Yakutia). Earth Surface Processes and Landforms, 28, 1349-1359. https://doi.org/10.1002/ esp.592

Fedorov, A. N., Ivanova, A., Park, R., Hiyama, H., \& Iijima, Y. (2014). Recent air temperature changes in the permafrost landscapes on northeastern Eurasia. Polar Science, 8(2), 114-128. https://doi.org/10.1016/j.polar.2014.02.001

Fedorov, A. N., \& Konstantinov, P. Y. (2009). Response of permafrost landscapes of central Yakutia to current changes of climate, and anthropogenic impacts. Geography and Natural Resources, 30, 146-150. https://doi.org/10.1016/j.gnr.2009.06.010

French, H. M. (2017). The periglacial environment (4th ed.). Wiley.

Grosse, G., Harden, J., Turetsky, M., McGuire, A. D., Camill, P., Tarnocai, C., et al. (2011). Vulnerability of high-latitude soil organic carbon in North America to disturbance. Journal of Geophysical Research, 116, G00K06. https://doi.org/10.1029/2010JG001507

IPCC. (2019). In H.-O. Pörtner, et al. (Eds.), IPCC special report on the ocean and Cryosphere in a changing climate.

Kizyakov, A. I., Zimin, M. V., Leibman, M. O., \& Pravikova, N. V. (2013). Monitoring of the rate of thermal denudation and thermal abrasion on the western coast of Kolguev Island, using high resolution satellite images. Kriosfera Zemli, 17(4), 36-47.

Kokelj, S. V., \& Jorgenson, M. T. (2013). Advances in thermokarst research. Permafrost and Periglacial Processes, 24(2), 108-119. https:// doi.org/10.1002/ppp.1779

Kokelj, S. V., Lantz, T. C., Tunnicliffe, J., Segal, R., \& Lacelle, D. (2017). Climate-driven thaw of permafrost preserved glacial landscapes, northwestern Canada. Geology, 45(2). https://doi.org/10.1130/G38626.1

Lacelle, D., Bjornson, J., \& Lauriol, B. (2010). Climatic and geomorphic factors affecting contemporary (1950-2004) activity of retrogressive thaw slumps on the Aklavik Plateau, Richardson Mountains, NWT, Canada. Permafrost and Periglacial Processes, 21, 1-15. https://doi. org/10.1002/ppp.666

Lantuit, H., \& Pollard, W. H. (2008). Fifty years of coastal erosion and retrogressive thaw slump activity on Herschel Island, southern Beaufort Sea, Yukon Territory, Canada. Geomorphology, 95(1). https://doi.org/10.1016/j.geomorph.2006.07.040

Lantuit, H., Pollard, W. H., Couture, N., Fritz, M., Schirrmeister, L., Meyer, H., \& Hubberten, H.-W. (2012). Modern and late Holocene retrogressive thaw slump activity on the Yukon coastal plain and Herschel Island, Yukon Territory, Canada. Permafrost and Periglacial Processes, 23, 39-51. https://doi.org/10.1002/ppp.1731

Lantz, T. C., \& Kokelj, S. V. (2008). Increasing rates of retrogressive thaw slump activity in the Mackenzie Delta region, N.W.T., Canada. Geophysical Research Letters, 35, L06502. https://doi.org/10.1029/2007GL032433

Leibman, M., Gubarkov, A., Khomutov, A., Kizyakov, A., \& Vanshtein, B. (2008). Coastal processes at the tabular-ground-ice-bearing area, Yugorsky Peninsula, Russia. In D. L. Kane \& K. M. Hinkel (Eds.), Proceedings of the Ninth International Conference on Permafrost (pp. 1037-1042). University of Alaska Fairbanks.

Lewkowicz, A. G., \& Way, R. G. (2019). Extremes of summer climate trigger thousands of thermokarst landslides in a High Arctic environment. Nature Communications, 10, 1329. https://doi.org/10.1038/s41467-019-09314-7

Murton, J., Edwards, M., Lozhkin, A., Anderson, P., Savvinov, G., Bakulina, N., et al. (2017), Preliminary paleoenvironmental analysis of permafrost deposits at Batagaika megaslump, Yana Uplands, northeast Siberia. Quaternary Research, 87(2), 314-330. https://doi. org/10.1017/qua.2016.15

Nitze, I., Grosse, G., Jone, B. M., Romanovsky, V. E., \& Boike, J. (2018). Remote sensing quantifies widespread abundance of permafrost region disturbances across the Arctic and Subarctic. Nature Communications, 9, 5423. https://doi.org/10.1038/s41467-018-07663-3 
Obu, A., Lantuit, H., Fritz, M., Pollard, W. H., Sachs, T., \& Günther, F. (2016). Relation between planimetric and volumetric measurements of permafrost coast erosion: A case study from Herschel Island, western Canadian Arctic. Polar Research, 35, 1. https://doi.org/10.3402/ polar.v35.30313

Olefeldt, D., Goswami, S., Grosse, G., Hayes, D., Hugelius, G., Kuhry, P., et al. (2016), Circumpolar distribution and carbon storage of thermokarst landscapes. Nature Communications, 7, 13043. https://doi.org/10.1038/ncomms13043

Opel, T., Murton, J. B., Wetterich, S., Meyer, H., Ashastina, K., Günther, H., et al. (2019). Past climate and continentality inferred from ice wedges at Batagay megaslump in the Northern Hemisphere's most continental region, Yana Highlands, interior Yakutia. Climate of the Past, 15, 1443-1461. https://doi.org/10.5194/cp-15-1443-2019

Romanovsky, V. E., Smith, S. L., \& Christiansen, H. H. (2010). Permafrost thermal state in the polar northern Hemisphere during the international polar year 2007-2009: A synthesis. Permafrost and Periglacial Processes, 21, 106-116. https://doi.org/10.1002/ppp.689

Rudy, A. C. A., Lamoureux, S. F., Kokelj, S. V., Smith, I. R., \& England, J. H. (2017). Accelerating thermokarst transforms ice-cored terrain triggering a downstream cascade to the ocean. Geophysical Research Letters, 44, 11080-11087. https://doi.org/10.1002/2017GL074912

Schirrmeister, L., Dietze, E., Matthes, H., Gross, G., Strauss, J., Laboor, S., et al. (2020). The genesis of Yedoma Ice Complex permafrostgrain-size endmember modeling analysis from Siberia and Alaska. E\&G Quaternary Science Journal, 69, 33-53. https://doi.org/10.5194/ egqsj-69-33-2020

Schuur, E. A. G., Bockheim, J., Canadell, J. G., Euskirchen, E., Field, C. B., Goryachkin, S. V., et al. (2008), Vulnerability of permafrost carbon to climate change: Implications for the global carbon cycle. BioScience, 58(8), 701-714. https://doi.org/10.1641/B580807

Segal, R. A., Lantz, T. C., \& Kokelj, S. V. (2016). Acceleration of thaw slump activity in glaciated landscapes of the Western Canadian Arctic. Environmental Research Letters, 11(3). https://doi.org/10.1088/1748-9326/11/3/034025

Séjourné, A., Costard, F., Fedorov, A., Gargani, J., Skorve, J., \& Massé, M. (2015). Evolution of the banks of thermokarst lakes in central Yakutia due to retrogressive thaw slump activity controlled by insolation. Geomorphology, 241, 31-40. https://doi.org/10.1016/j. geomorph.2015.03.033

Shakil, S., Tank, S. E., Kokelj, S. V., Vonk, J. E., \& Zolkos, S. (2020). Particulate dominance of organic carbon mobilization from thaw slumps on the Peel Plateau, NT: Quantification and implications for stream systems and permafrost carbon release. Environmental Research Letters, 15(11). https://doi.org/10.1088/1748-9326/abac36

Shepelev, A. G., Kizyakov, A., Wetterich, S., Cherepanova, A., Fedorov, A., Syromyatnikov, I., \& Savvinov, G. (2020). Sub-surface carbon stocks in northern taiga landscapes exposed in the Betagay Megaslump, Yanal upland, Yakutia. Land, 9, 305. https://doi.org/10.3390/ land9090305

Soloviev, P. A. (1973). Thermokarst phenomena and landforms due to frost heaving in central Yakutia. Biuletyn Peryglacjalny, 23, 135-155.

Strauss, L., Schirrmeister, J., Grosse, G., Fortier, D., Hugelius, G., Knoblauch, C., et al. (2017), Deep Yedoma permafrost: A synthesis of depositional characteristics and carbon vulnerability. Earth-Science Reviews, 172, 75-86. https://doi.org/10.1016/j.earscirev.2017.07.007

Tohari, A., Nishigaki, M., \& Komatsu, M. (2007). Laboratory rainfall-induced slope failure with moisture content measurement. Journal of Geotechnical and Geoenvironmental Engineering, 3(5), 575. https://doi.org/10.1061/(ASCE)1090-0241(2007)133:5(575)

Turetsky, M. R., Abbott, B. W., Jones, M. C., Anthony, K. W., Olefeldt, D., Schuur, E. A. G., et al. (2020). Carbon release through abrupt permafrost thaw. Nature Geoscience 13, 138-143. https://doi.org/10.1038/s41561-019-0526-0

Ulrich, M., Grosse, G., Strauss, J., \& Schirrmeister, L. (2014). Quantifying wedge-ice volumes in Yedoma and thermokarst basin deposits. Permafrost and Periglacial Processes, 25, 151-161. https://doi.org/10.1002/ppp.1810

Vonk, J. E., Tank, S. E., Bowden, W. B., Laurion, I., Vincent, W. F., Alekseychik, P., et al. (2015). Reviews and syntheses: Effects of permafrost thaw on Arctic aquatic ecosystems. Biogeosciences, 12, 7129-7167. https://doi.org/10.5194/bg-12-7129-2015

Ward Jones, M. K., Pollard, W. H., \& Jones, B. M. (2019). Rapid initialization of retrogressive thaw slumps in the Canadian high Arctic and their response to climate and terrain factors. Environmental Research Letters, 14(5). https://doi.org/10.1088/1748-9326/ab12fd

Wolfe, S., Kotler, E., \& Dallimore, S. (2001). Surficial characteristics and the distribution of thaw landforms (1970-1999), shingle point to kay point, Yukon territory. Geological Survey of Canada Open File 4115.

Zwieback, S., Kokelj, S. V., Günther, F., Boike, J., Grosse, J., \& Hajnsek, I. (2018). Sub-seasonal thaw slump mass wasting is not consistently energy limited at the landscape scale. The Cryosphere, 12, 549-564. https://doi.org/10.5194/tc-12-549-2018 